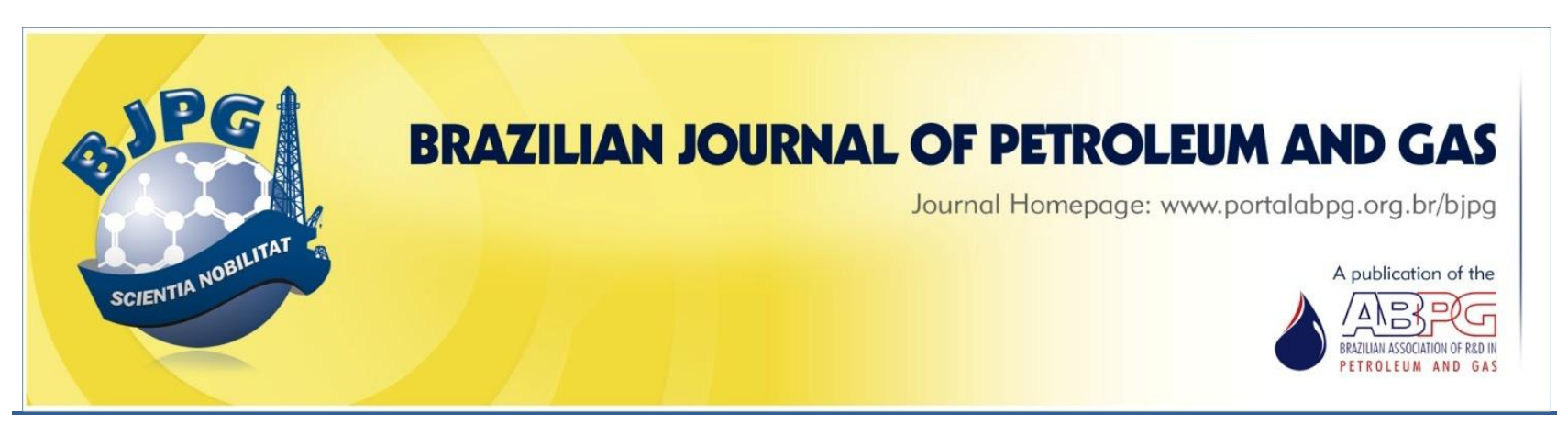

\title{
EFFECT OF BIODIESEL/DIESEL-BASED MICROEMULSIONS ON THE EXHAUST EMISSIONS OF A DIESEL ENGINE
}

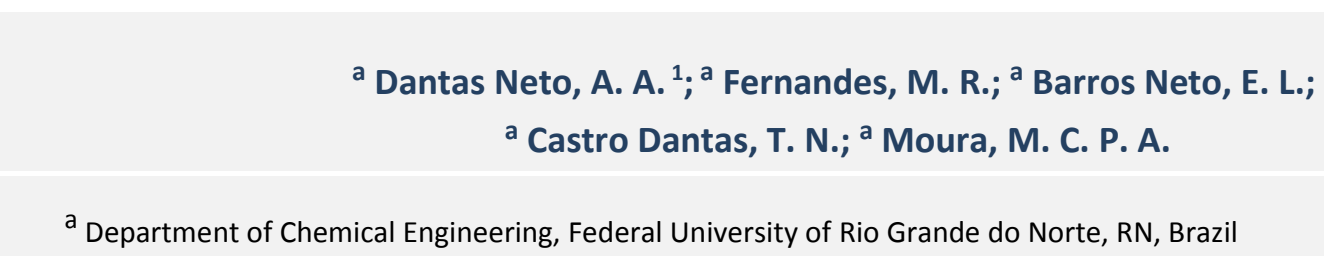

${ }^{a}$ Department of Chemical Engineering, Federal University of Rio Grande do Norte, RN, Brazil

\begin{abstract}
This paper describes the use of blends of diesel/biodiesel to obtain new microemulsion systems and their application as fuels for diesel engines. The blends were prepared using 5 vol.\% (B5) and 20 vol.\% (B20) biodiesel in diesel. The microemulsions were composed by either B5 or B20 as oil phase, nonylphenol ethoxylate with five oxyethylene units as nonionic surfactant, and distilled water as aqueous phase. Properties such as viscosity, flash point, density, and corrosiveness were evaluated. In comparison with diesel, increases in viscosity, density, and flash point were observed. Although increase in corrosiveness could be expected, this was not detected with the blends, which were fueled in a diesel engine to evaluate gaseous emissions. A reduction in $\mathrm{CO}, \mathrm{NOx}$ and smoke emissions was observed, together with an increase in the emissions of unburned hydrocarbons. Therefore, the results indicate that the exhaust emissions of these novel microemulsion systems presented lower pollutants than neat diesel.
\end{abstract}

\section{KEYWORDS}

diesel engine; diesel; biodiesel; surfactant; microemulsion; exhaust emissions

\footnotetext{
${ }^{1}$ To whom all correspondence should be addressed.

Address: Universidade Federal do Rio Grande do Norte - UFRN, Centro de Tecnologia, Departamento de Engenharia Química, Campus Universitário, Natal, Rio Grande do Norte, RN - Brazil - CEP 59072-970

Telephone / Fax: +55 84 3215-3773 / +55 84 3215-3156 | E-mail: aadantas@eq.ufrn.br doi:10.5419/bjpg2013-0012
} 


\section{INTRODUCTION}

Biodiesel can be produced using several raw materials, including vegetable oils, animal fats, and even used cooking oils. Typically, biodiesel can be obtained from the transesterification reaction of vegetable oils or animal fats using a short-chain alcohol (methanol or ethanol), in the presence of basic or acidic catalysts, producing methyl or ethyl esters (biodiesel) and glycerin (Atadashi et al.,2010; Fazal et al., 2011).

Biodiesel usually contains up to $10 \%$ of oxygen in its molecule $(w / w)$, for which reason it can be considered as an oxygenated fuel. The high concentration of oxygen enhances the efficiency in combustion and reduces the emissions of particulate matter, carbon monoxide, and other polluting gases. As reported in the literature, the combustion of biodiesel produces around $5 \%$ to 10 $\%$ more nitrogen oxides (NOx) than that of neat diesel (Dorado et al., 2003; Hess et al., 2005; Szybist et al., 2005; Grabowski et al., 1998; Lin et al., 2006; Lin \&Lin, 2006).

Biodiesel can be fueled pure or blended with diesel fuel for use in diesel engines. Its addition in small amounts to diesel gives better lubricity characteristics and minimizes the emissions of particulates and gaseous pollutants, besides avoiding further NOx emissions obtained by burning only biodiesel. According to Janaun \& Ellis (2010), these blends are commercially named as B5, when the blends contain 5 vol.\% biodiesel and 95 vol.\% diesel, and as B20, when the blends have 20 vol.\% biodiesel and 80 vol.\% diesel. Brazil is one of the countries that largely use B5 blends as fuel for vehicles.

As far as commercial standards are concerned, the maximum allowable amount of biodiesel in the blend is 20 vol.\%. Mixtures with up to $20 \%$ biodiesel can be used in a diesel engine without requiring any modification because the flow properties of the diesel predominate. Biodiesel also presents disadvantages that include: low chemical and thermal stabilities, poor cold flow properties, formation of wax when exposed to low temperatures, and high viscosity if compared with neat diesel. The oxidation of biodiesel at increasing temperatures leads to an increase in viscosity, which results in the formation of sediments that contribute to the clogging of filters and injection systems.

Surfactants are organic compounds used to reduce the interface tension between oil and water phases. As amphiphilic molecules, they contain at least one lyophilic and one lyophobic group. Several authors have used surfactants to obtain diesel-based microemulsions, such as: Cetyltrimethylammonium chloride (CTAC) (Wang et al., 2008), sodium lauryl sulfate (Texapon HBN), diethanolamides of coconut fatty acids (Comperlan SCD) (Castro Dantas et al., 2001), penta(ethylene glycol)monoundecyl ether and sorbitan monooleate (Ochoterena et al., 2010), KENON 10 and KENON 4 (ethoxylated nonylphenol with 10 and 4 ethoxylation degree) (Shariati et al., 2007), combinations of sorbitan monooleate and alcohol ethoxylates (Lif et al., 2010), and Span 80 (Sorbitan monooleate) (Kannan \& Anand, 2011; Qi et al., 2010), among other surfactants.

Microemulsions are clear, isotropic, and thermodynamically stable mixtures of a polar phase with a nonpolar phase obtained spontaneously with the aid of a surfactant and, sometimes, a co-surfactant. Castro Dantas et al. (2001) developed diesel-based microemulsions with blends of diesel and vegetable oils (soy, palm, and ricin oils). By constructing pseudoternary phase diagrams, the influences of the nature of surfactant (Texapon HBN and Comperlan SCD), cosurfactant and oil phases, as well as the surfactant/co-surfactant mass ratio, were investigated. The microemulsion composed by 13.50wt.\% Comperlan SDC $\quad(98 \%$ of diethanolamides of coconut fatty acids), $6.74 \mathrm{wt} . \%$ isoamyl alcohol, $63 \mathrm{wt} . \%$ neat diesel, $1 \mathrm{wt} . \%$ water, and $15 \mathrm{wt} . \%$ soy oil showed physical-chemical properties close to the ones presented by neat diesel, indicating the possibility of using this blend as an alternative fuel.

Lif et al. (2010) used Fischer-Tropsch diesel to produce emulsions and microemulsions using several sorbitan monooleate and alcohol ethoxylates mixtures as surfactants. The water content was set between 7 and $13 \%$. The stability of the emulsions was assessed as the volume of the water-rich phase formed on the bottom of the sample holder at different times, at $20^{\circ} \mathrm{C}$. The authors observed that the stability of the system can be enhanced by selecting a suitable mixture of surfactants in combination with a polymeric 
emulsion stabilizer. Combustion experiments in a single-cylinder diesel engine burning emulsion systems showed reduced emissions of soot and NOx.

Biodiesel features both hydrophilic and lipophilic moieties in its structure, and several authors have proposed its application as an additive with surfactant properties to prepare ethanol-diesel emulsions. Cheenkachorn et al. (2004) developed emulsification tests to select the best composition ethanol/palm-oil derived biodiesel/diesel, considering both emulsion stability and fuel properties. Subbaiah et al. (2010) evaluated the performance and emission characteristics of a diesel engine burning neat diesel, biodiesel (B100), a mixture of 90 vol.\% diesel and 10 vol.\% biodiesel (B10), and three blends of diesel/biodiesel/ethanol. They concluded that biodiesel can be used as an efficient additive to obtain diesel-biodiesel-ethanol blends with higher ethanol contents.

In a previous work, Dantas Neto et al. (2011) developed diesel-based microemulsions that were tested in a diesel engine to evaluate engine performance and type and level of emissions. Nonylphenol ethoxylate with five oxyethylene units (NP5EO) was used as surfactant. They observed an increase in $\mathrm{CO}$ emissions when compared with neat diesel. Specific fuel consumption of the microemulsion systems was greater than that of neat diesel, but the small droplets of water improved diesel combustion.

In this new research, microemulsion systems were developed using blends of biodiesel and diesel (B5 and B20), with the NP5EO surfactant. Literature references reporting the use of NP5EO with this purpose remain nonexistent. This surfactant was chosen due to its low ethoxylation degree, favoring the formation of water-in-oil microemulsions. The physicochemical properties of the microemulsion systems were determined. Then, a diesel engine was used to evaluate the gaseous emissions of the microemulsions, comparing the rates of emissions to the ones of neat diesel.

\section{MATERIALS AND METHODS}

\subsection{Materials}

The materials used for biodiesel synthesis were: refined soybean oil (commercial), ethanol (99.5\% purity), and sodium hydroxide (97.0\% purity), purchased from a local market (Cromato Produtos Químicos Ltda., Brazil).

The materials used for the preparation of microemulsion systems were: mineral diesel fuel (supplied by Petrobras), biodiesel (synthesized by the authors), nonylphenol ethoxylate 5 EO (NP5EO, commercial), and distilled water. The physicochemical properties of NP5EO are shown in Table 1.

Due to the presence of the ethoxylated group, NP5EO has low solubility in water, but is miscible with oil, favoring the formation of water-in-oil microemulsions. According to Ahel and Giger (1993), the solubility of this class of nonionic surfactant in water is based on the hydration of ether functional groups through hydrogen bonds. According to these authors, lower nonylphenol ethoxylate oligomers (NPnEO, with $n E O<5$ ) are

Table 1. Some physicochemical properties of NP5EO.

\begin{tabular}{lc}
\hline Propertie & Value \\
\hline Appearance, at $25^{\circ} \mathrm{C}$ & liquid \\
Acid Number $(\mathrm{mg} \mathrm{KOH} / \mathrm{g})$ & 1.0 max. \\
Hydroxyl Number $(\mathrm{mg} \mathrm{KOH} / \mathrm{g})$ & $121-134$ \\
Water (wt.\%) & 0.5 max. \\
${ }^{1} \mathrm{pH}$ & $5.0-7.5$ \\
${ }^{2} \mathrm{Cloud}$ Point $\left({ }^{\circ} \mathrm{C}\right)$ & $46-56$ \\
HLB Number (calculated) & 10.0 \\
\hline
\end{tabular}

(1) $1 \%$ wt./wt. solution propan-2-ol/water 1:2

(2) $20 \%$ wt./wt. solution (in butyl glycol, at $25 \%$ ) 


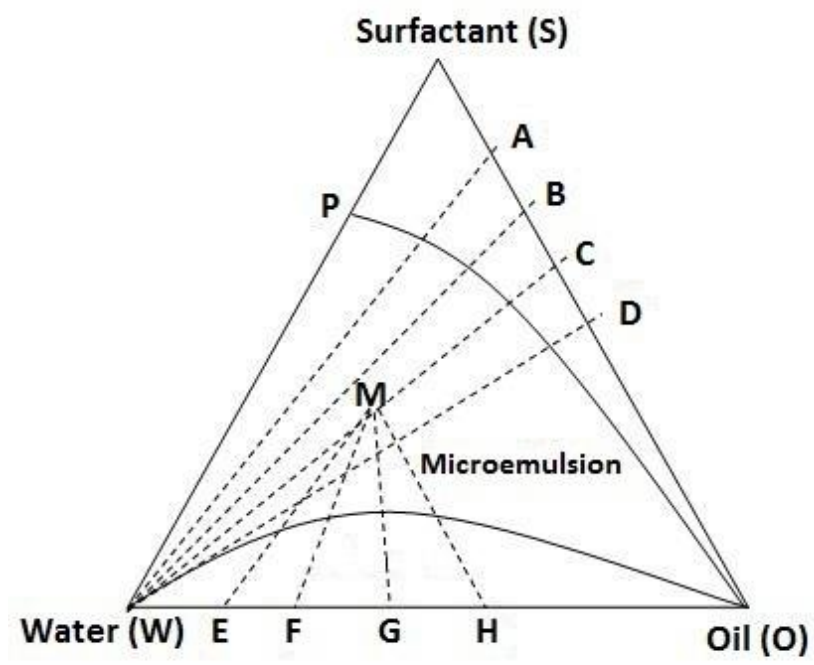

Figure 1. Ternary phase diagram with the indication of the method used to determine microemulsion regions (Dantas Neto et al., 2011).

usually described as "water insoluble" or lipophilic, and higher oligomers as "water soluble" or hydrophilic. They found that the solubility of NPnEO with 1 to 5 ethoxylated groups range between 3.0 and $9.5 \mathrm{mg} / \mathrm{L}$, increasing linearly with the increase in number of EO groups in the molecule.

\subsection{Biodiesel synthesis}

For the synthesis of biodiesel from soybean oil, a 6,000-mL jacketed glass reactor with round bottom was used. Initially, $1.5 \mathrm{~kg}(1,621.62 \mathrm{~mL})$ of soybean oil was heated for $1 \mathrm{~h}$ at $60^{\circ} \mathrm{C}$. Then, the alcohol solution was added $(10.5 \mathrm{~g}$ of $\mathrm{NaOH}$ dissolved in $760 \mathrm{~mL}$ of ethanol) and the mixture was stirred in a mechanical magnetic stirrer at $1,000 \mathrm{rpm}$ for $2 \mathrm{~h}$. Immediately after, the product was placed during $2 \mathrm{~h}$ in a rotary evaporator $(85 \mathrm{rpm}$ at $80^{\circ} \mathrm{C}$ ) to remove the excess alcohol from the mixture. After the removal of ethyl alcohol, the mixture was poured into a separating funnel, and allowed to settle for about $12 \mathrm{~h}$ in order to allow the two phases to separate. The upper phase was biodiesel and the lower phase was glycerin. The glycerin was drawn off and the biodiesel was washed 3 times (1:4 esters:water ratio) with warm water $\left(60^{\circ} \mathrm{C}\right)$ to remove the dissolved glycerol. To evaporate the excess water, the obtained product was heated in an oven at $110^{\circ} \mathrm{C}$ until its weight became constant.

\subsection{Microemulsion systems}

Figure 1 shows a schematic ternary phase diagram used to determine the microemulsion region. First, the point of maximum solubility of surfactant in the aqueous phase (P) was determined by weighing a certain amount of surfactant and titrating it with water until the system changed from cloudy to clear. After, to determine the lateral boundary of the microemulsion region, points in the Surfactant (S)/Oil (O) binary systems (A, B, C, and D) were prepared by mixing the surfactant with the oil phase at different surfactant fractions and titrating each point with water (W) until the cloudy system became clear. The lower limit was determined by preparing points in the Water $(W) / O i l(O)$ binary $(E$, $F, G$ and $H$ ) with different water fractions and titrating each point with a previously prepared microemulsion (M) until the system changed from a two-phase system to an optically monophasic system (clear aspect). The $\mathrm{M}$ point was prepared by taking one point in the S/O binary and titrating it with water, observing the change from cloud to clear (boundary) and adding more water to obtain a microemulsion inside the monophasic area, checking that the system had to remain clear. The amounts of water (W), oil (O), and surfactant (S) in each point were obtained by mass balance. A highspeed centrifuge (Cientec - Model CT-5000R) was used to test the physical stability of the microemulsion systems (30 minutes at $6,000 \mathrm{rpm}$ ). The ternary phase diagrams were obtained at $28^{\circ} \mathrm{C}$. 
Table 2. Composition of the microemulsion systems tested.

\begin{tabular}{lccccc} 
& \multicolumn{5}{c}{ Composition (\% of weight/weight) } \\
\hline System & Diesel (B0) & B5 & B20 & NP5EO & Distilled water \\
\hline Diesel (B0) & 100 & - & - & - & - \\
Diesel/biodiesel (B5) & - & 100 & - & - & - \\
Diesel/biodiesel (B20) & - & - & 100 & - & - \\
System 1 (S1) & - & 81 & - & 15 & 4 \\
System 2 (S2) & - & 77 & - & 15 & 8 \\
System 3 (S3) & - & 73 & - & 15 & 12 \\
System 4 (S4) & - & - & 81 & 15 & 4 \\
System 5 (S5) & - & - & 77 & 15 & 8 \\
System 6 (S6) & - & - & 73 & 15 & 12 \\
\hline
\end{tabular}

Table 3. Specifications of the diesel engine.

\begin{tabular}{lc}
\hline Model & BD H 5.0 \\
Type & single-cylinder, air-cooled, horizontal, 4-stroke \\
Combustion system & direct injection \\
Engine speed & $3000 / 3600 \mathrm{rpm}$ \\
Maximum output & $4.2 / 4.7 \mathrm{hp}$ \\
\hline
\end{tabular}

\subsection{Preparation of diesel/biodiesel blends and microemulsion systems}

Diesel/biodiesel blends were prepared with 0 vol. $\%, 5$ vol.\%, and 20 vol.\% of biodiesel in diesel, which were called B0, B5, and B20, respectively. The microemulsion systems were prepared using B5 or B20 as oil phase, NP5EO as surfactant, and distilled water as aqueous phase. The concentration of NP5EO in the systems was set at $15 w t . \%$ allowing to assess the effect of increasing the concentration of water in the systems, from 4 to $12 \mathrm{wt}$.\%. The composition of each microemulsion point is shown in Table 2.

\subsection{Characterization of microemulsion systems}

The density at $20^{\circ} \mathrm{C}$ was measured using an Anthony Parr density meter, model DMA 4500M. The kinematic viscosity measurements were obtained by using a HAAKE MARS (RS150) rheometer, at $40^{\circ} \mathrm{C}$ and $150 \mathrm{rpm}$ shear rate, during 200 seconds. The flash point was obtained using a semi-automatic closed-cup Pensky-Martens PM4 apparatus, manufactured by Petroteste, at a $1.0^{\circ} \mathrm{C} / \mathrm{min}$ heating rate. Corrosiveness measurements were performed at $50^{\circ} \mathrm{C}$ in a
Koehler apparatus (K25319 Model), using copper strips $(12.5 \times 75.0 \times 1.5 \mathrm{~mm})$ as working electrode, with surfaces polished with 240 grit silicon carbide paper, which were immersed during 3 hours in a sealed stainless steel container with $150 \mathrm{~mL}$ of the fluid to be tested. After this time, the strips were removed from the fluid, washed with hexane, and immediately rated by comparison with lithographed standard strips according to ASTM D130 (2004). In this ASTM standard there are four levels of increasing sulfur-related corrosion, where "1" corresponds to a slightly tarnished strip, "2" corresponds to a moderate tarnished strip, " 3 " corresponds to a dark tarnished strip, and "4" corresponds to a corroded strip. Within these numerical ratings, alphabetic sub-ratings were used to describe differences in color and pattern, with increasing corrosion levels ranging from "a" to "e" (Andersen et al., 2003).

\subsection{Exhaust gas analysis}

The specifications of the diesel engine used during experimental procedure are given in Table 3.

Emissions experiments were performed using a dynamometer, as schematically shown in Figure 2 (1). The engine rotation was set at $3500 \mathrm{rpm}$ using 


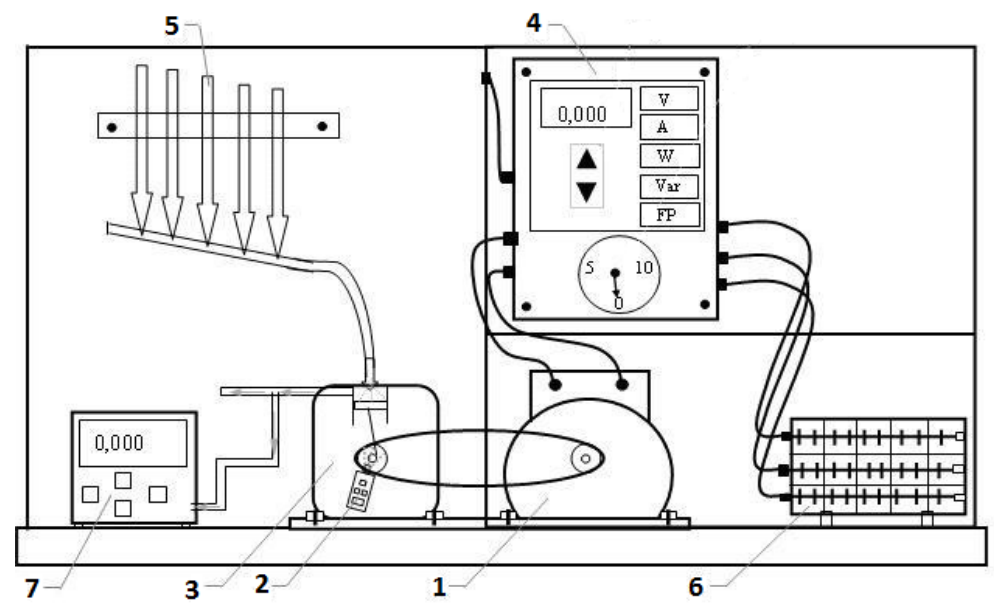

Figure 2. Main components of the experimental set up: 1- Electrical dynamometer, 2- Tachometer, 3- Diesel engine, 4- Multi-k unit, 5- Fuel feeding system, 6- Energy dissipation system, 7- Emission-analyzer equipment

(Dantas Neto et al., 2011).

a tachometer (2). The diesel engine (3) worked at the following power settings: $0.33,1.00,1.33$, and $2.00 \mathrm{~kW}$ (4). The fuel feeding system (5) was composed by five inputs, each with an individual testing tube, which enabled carrying out assays with individual samples under the same experimental conditions. The fuel flow rate was measured volumetrically. The energy generated by the diesel engine was dissipated by using an energy dissipation system (6).

Emissions of carbon monoxide (CO), nitrogen oxide (NOx), and total unburned hydrocarbons (HC) were determined by using a GreenLine 8000 emission analyzer (7) with the aspiration pump placed at the end of the engine's gas pipe. The smoke level in the exhaust gases was measured using a smoke pump (smoke tester 7828 Eurotron), according to ASTM D2156 (2009). This method consisted of collecting a sample, through gas suction, from the center of the engine's gas pipe using a special filter paper. The color of the spot left on the filter was compared against a numbered reference scale also known as "smoke index" (a gray-toned scale sheet that is divided in 10 distinct areas that range from 0 to 9 , where the number 0 represents $85 \% \pm 2.5 \%$ reflection). Every new area reflects $10 \%$ less than the previous one (Eurotron, 2010).

\section{RESULTS AND DISCUSSION}

\subsection{Ternary phase diagram}

Figure 3 shows the ternary phase diagram for systems composed by distilled water as aqueous phase, NP5EO as surfactant, and diesel, B5 or B20 as oil phase. One can observe that the microemulsion region exhibits a slight decline when there is an increase in the biodiesel content in the oil phase.

The formation of water-in-oil microemulsions depends on the interactions of the surfactant tail with the organic phase. In this case, an increment in the concentration of biodiesel in the organic phase increases the proportion of carbonyl moieties in the mixture, generating steric hindrance between the oil phase and the surfactant tail, which thereby acts hindering the formation of microemulsions.

\subsection{Fuel characterization}

Table 4 shows the physicochemical properties of the studied fuels and the allowed values according Brazilian legislation for neat diesel and biodiesel/diesel blends (ANP, 2006). 


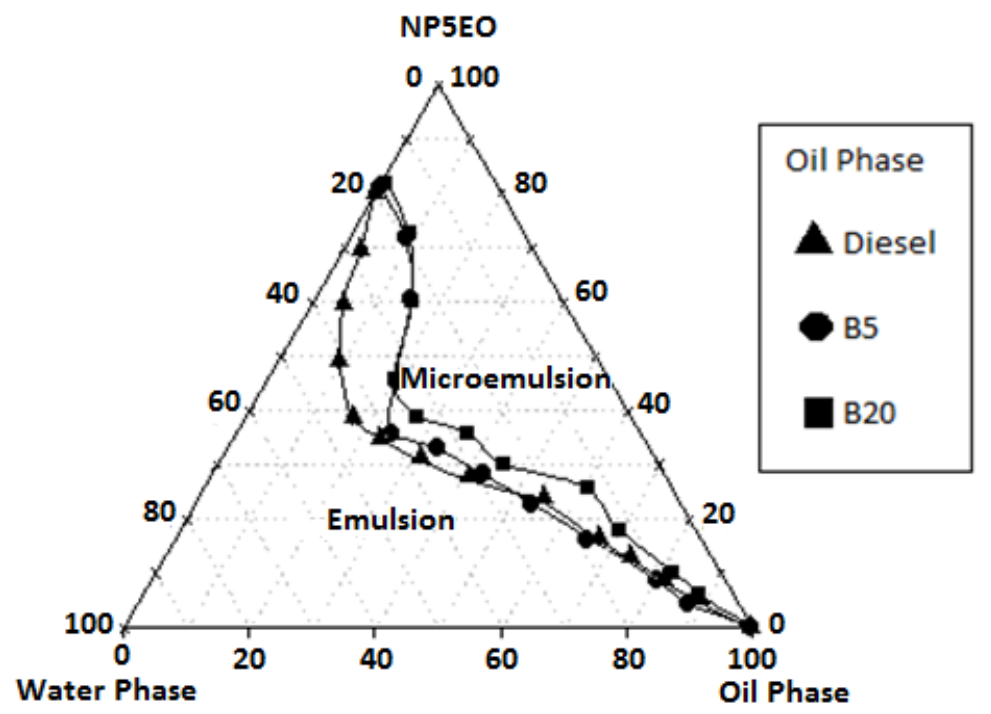

Figure 3. Ternary phase diagram showing the microemulsion region for the systems composed by water as aqueous phase, NP5EO as surfactant, and diesel, B5, and B20 as oil phase, at $28^{\circ} \mathrm{C}$.

An increase in density and flash point was observed for all studied systems as compared to neat diesel, but in accordance with Brazilian legislation. This increase in density is related with the amount of water and biodiesel present in the systems, which have a higher density than the diesel. The increase in flash point can also be related to the presence of biodiesel and water in the blend. The flash point for neat biodiesel is around $172^{\circ} \mathrm{C}$, which is significantly higher than the one for neat diesel (around $45^{\circ} \mathrm{C}$ ). For microemulsions, it is important to consider the presence of water vapor, which makes the mixture more fuel-poor.

Table 4. Physicochemical properties of the tested systems.

\begin{tabular}{|c|c|c|c|c|c|c|c|c|c|c|c|c|}
\hline \multirow[t]{2}{*}{ Parameter } & \multirow{2}{*}{$\begin{array}{l}\text { ASTM } \\
\text { D6751 }\end{array}$} & \multirow{2}{*}{$\operatorname{ANP}^{(1)}$} & \multicolumn{10}{|c|}{ System } \\
\hline & & & BO & B5 & B20 & B100 & S1 & $\mathbf{S 2}$ & S3 & S4 & S5 & S6 \\
\hline $\begin{array}{l}\text { Density } \\
\left(20^{\circ} \mathrm{C}-\mathrm{kg} / \mathrm{m}^{3}\right)\end{array}$ & - & $820-880$ & 820 & 833 & 849 & 871.6 & 858 & 864 & 871 & 871 & 873 & 877 \\
\hline $\begin{array}{l}\text { Flash Point (min.) } \\
\left({ }^{\circ} \mathrm{C}\right)\end{array}$ & 93 & 38 & 43.0 & 45.6 & 48.8 & 172.0 & 44.5 & 45.3 & 45.6 & 46.2 & 47.3 & 47.7 \\
\hline $\begin{array}{l}\text { Viscosity (max.) } \\
\left(40^{\circ} \mathrm{C}-\mathrm{cSt}\right)\end{array}$ & $1.9-6.0$ & $2.0-5.0$ & 2.2 & 2.8 & 3.6 & 4.4 & 5.8 & 6.7 & 7.7 & 5.9 & 7.0 & 8.1 \\
\hline $\begin{array}{l}\text { Corrosiveness } \\
\text { (max.) } \\
\left(3 \mathrm{~h}-50^{\circ} \mathrm{C}\right)\end{array}$ & 3 & 1 & $1 a^{(2)}$ & $1 a$ & $1 b^{(3)}$ & $1 b$ & $1 a$ & $1 a$ & $1 a$ & $1 a$ & $1 a$ & $1 a$ \\
\hline Cloud point $\left({ }^{\circ} \mathrm{C}\right)$ & - & - & 15.5 & 16.8 & 16.5 & - & 16.4 & 16.5 & 16.5 & 16.2 & 16.4 & 16.5 \\
\hline Sulfur (ppm) & 500 & $<1800$ & 175.6 & 163.8 & 136.8 & 0.0 & 118.6 & 108.4 & 84.2 & 104.2 & 95.7 & 80.0 \\
\hline $\begin{array}{l}\text { Cetane number } \\
(\min .)^{(4)}\end{array}$ & 47 & 45 & 52.2 & 53.2 & 53.7 & 61.5 & - & - & - & - & - & - \\
\hline
\end{tabular}
(1) ANP - Brazilian National Agency of Petroleum, Natural Gas, and Biofuels;
(2) 1a - light orange, almost the same as a freshly polished strip;
(3) 1 b - dark orange;
(4) For S1 to S6 the cetane number was not measured due to the presence of water. 

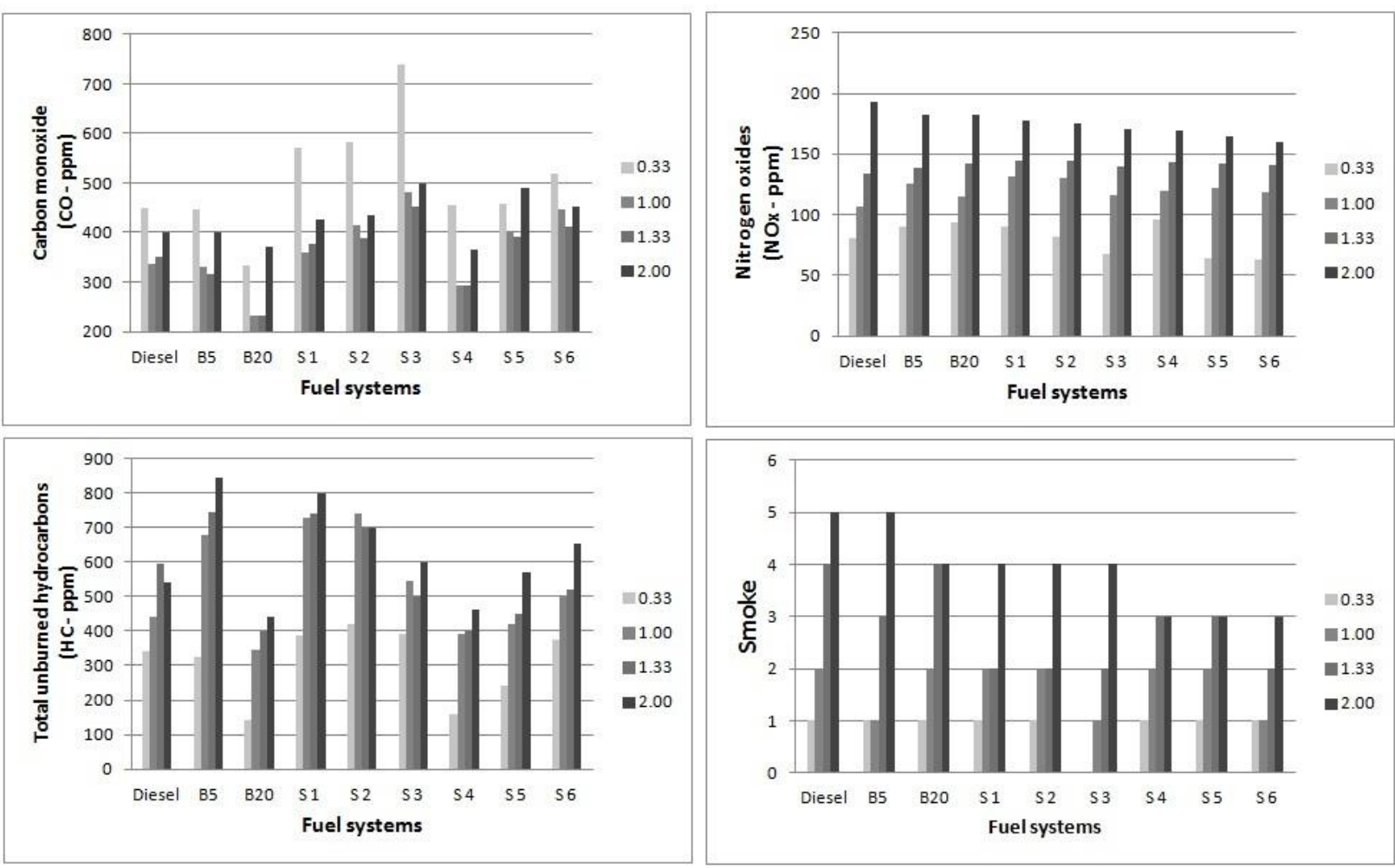

Figure 4. Emissions of carbon monoxide (CO), total unburned hydrocarbons (HC), nitrogen oxides (NOx), and smoke as a function of the used fuel system and power setting $(0.33,1.00,1.33$, and $2.00 \mathrm{~kW})$.

The values of viscosity failed to meet the Brazilian legislation standards and showed a direct relationship with the amount of water and biodiesel (high viscosity) added to the system. Water is the dispersed phase of the water-in-oil microemulsions. The surfactant interacts with the water phase favoring the formation of more complex micellar structures.

With respect to corrosion, an increase in corrosiveness was expected for microemulsion systems due to the presence of water in its composition. This behavior was not observed because all studied systems are water-in-oil microemulsions, with the aqueous phase dispersed as small droplets inside the oil-continuous phase. The water content in the samples is relatively low to produce any considerable corrosive effects.

The cloud point for diesel, B5, B20, and all microemulsion systems remained almost constant and were elevated if compared with literature data (Benjumea et al., 2008; Balat $\&$ Balat, 2008). This may be related with the content of paraffin, as proposed by Dantas Neto et al. (2009). For systems 1 to 6 , the sulfur content decreased with increasing amounts of water and biodiesel in the systems.

\subsection{Emissions pattern}

The results for the emissions of carbon monoxide (CO), nitrogen oxides (NOx), total unburned hydrocarbons $(\mathrm{HC})$ and smoke levels as a function of engine power are shown in Figure 4.

As shown in Figure 4, the exhaust emissions of CO from B5 and B20 are lower than those from neat diesel. As expected, and in accordance with the literature, an increase in the amount of biodiesel in diesel/biodiesel blend reduces carbon monoxide emissions due to the presence of oxygen in biodiesel, which favors complete combustion inside the cylinder chamber (Khan et al., 1971; Khan et al., 1972; Rakopoulos et al., 2006; Kannan \& Anand, 2011). In a general trend, microemulsion systems showed increasing $\mathrm{CO}$ emissions with the increase in water content and a reduction in $\mathrm{CO}$ emissions was observed with an increase in engine power and biodiesel content. This reduction in $\mathrm{CO}$ emissions with the increase in engine power is related to the temperature inside the cylinder chamber. As well reported, water in the form of emulsion or microemulsion tends to increase $\mathrm{CO}$ emissions due to a reduction in the temperature inside the cylinder chamber, which causes a 
decrease in combustion efficiency (Abu-Zaid, 2004; Lif et al., 2010).

Evaluating NOx emissions, for microemulsion systems a decrease in NOx formation was observed with increasing water content and engine power. According to Turns (1995) and Mueller et al. (2009), the thermal mechanism for NOx formation consists in the following reactions involving $\mathrm{N}$ and $\mathrm{O}$ atoms: $\mathrm{N}_{2}+\mathrm{O} \rightarrow \mathrm{NO}+\mathrm{N}, \mathrm{O}_{2}+\mathrm{N} \rightarrow \mathrm{NO}+\mathrm{O}$, and $\mathrm{OH}+\mathrm{N} \rightarrow \mathrm{NO}+\mathrm{H}$. The simple rate expression for NO formation when NO concentrations are well below equilibrium is given by:

$\frac{d[N O]}{d t}=2 k[O]\left[N_{2}\right]$

Where [NO], [O], and $\left[\mathrm{N}_{2}\right]$ are nitric oxide, atomic oxygen, and molecular nitrogen concentrations. The reaction-rate coefficient is given by:

$k=B T^{\alpha} \exp \left(\frac{-E_{a}}{R_{u} T}\right)$

Where $B, \alpha_{1}, E_{a}$, and $R_{\mathrm{u}}$ are constants. As indicated by Eq. 2 , the reaction rate coefficient $(k)$ increases as a direct function of temperature. As in Eq. 2, the thermal NO production rate is proportional to $k$, when temperature is reduced due to the presence of water in the microemulsion systems. There is also a reduction in the formation of thermal NO. This phenomenon occurs due to the boiling point of water being lower than that of diesel, leading to a reduction in the temperature inside the combustion chamber, reducing the thermal NO formation and thus also reducing NOx formation. It is also important to consider that, when a microemulsion is injected, the microdroplets of diesel contain water, which has higher latent heat and will rapidly evaporate, causing micro-explosions, enhancing atomization and increasing the contact area between air and oil, therefore improving fuel combustion.

The increase in NOx emissions with an increase in concentration of biodiesel in diesel was observed by several authors (Khan et al., 1972; Khan et al., 1971; Rakopoulos et al., 2006; Zheng et al., 2008). According to Lin \& Lin (2008), high nitrogen oxides (NOx) are frequently produced when burning biodiesel primarily because it is an oxygenated fuel. Ban-Weiss et al. (2007) also related this NOx formation with a longer ignition delay time, making the reactants in the combustion chamber to be increasingly preheated, rising the flame temperature and therefore causing higher NOx emissions.

Mueller et al. (2009) reports several hypotheses that have been proposed to explain the biodiesel NOx increase. One of these hypotheses is that "biodiesel produces less soot because it is an oxygenated fuel. Because soot radiation is the primary means of heat loss from an in-cylinder flame, radiation heat losses are lower for biodiesel flames, which produce higher actual flame temperatures and more thermal NOx". In the case of microemulsions with biodiesel blends, the water present in the mixture decreases in-cylinder temperatures and, consequently, reduces NOx emissions.

Total unburned hydrocarbon (HC) emissions from $\mathrm{B} 5$ were higher than the ones registered from neat diesel and this difference increased with the increase in engine power. For B20, a reduction in $\mathrm{HC}$ emissions was observed for all engine powers. The expected behavior for biodiesel/diesel blends is a decrease in $\mathrm{HC}$ emissions due to the higher oxygen content and cetane number of biodiesel, as compared with neat diesel.

B5- and B20-based microemulsions showed increasing $\mathrm{HC}$ emissions with increasing water content within the systems. As previously explained, this is related to the high latent heat of vaporization of water responsible for reducing the gas temperature inside the cylinder, which causes a decrease in combustion efficiency (Kannan \& Anand, 2011; Lif et al., 2010).

Smoke emissions from diesel/biodiesel blends (B5 and B20) and microemulsion systems were equal or lower than the values attributed to neat diesel. Studies show that the addition of biodiesel to diesel contributes to reduce the levels of particulate matter (Rakopoulos, 2006; Zheng et al., 2008). This reduction occurs due to the absence of sulfur in biodiesel, since sulfur is an antecedent in particulate matter formation. Therefore, the higher the concentration of biodiesel in diesel, the smaller the amount of sulfur, and, consequently, the emissions of particulate matter and smoke diminish.

The smoke level decreased with the increase in water content. The presence of water in 
microemulsions reduces the combustion temperature. This reduction in temperature occurs due to water vaporisation and the dilution effect of water, consequently decreasing the production of soot (Tauzia et al., 2010)

According to Ochoterena et al. (2010), the use of diesel-based emulsions and microemulsions reduced between $81 \%$ and $89 \%$ exhaust soot emissions, respectively. They attributed this reduction to the combined effects of lower flame temperatures, lower concentration of soot in the flames, rapid evaporation of water, and the presence of hydroxyl radicals from water dissociation. Also, Subramanian (2011) related the reduction in smoke emissions to the microexplosions phenomenon, and Qi et al. (2010) attributed the results to improved vaporization and atomization. All these factors lead to an improved air-fuel mixing and, consequently, to better combustion.

\section{CONCLUSIONS}

Biodiesel/diesel blends (B5 and B20) and six microemulsion systems were prepared and their physicochemical properties were compared with the ones of neat diesel. Also, a single cylinder 4stroke diesel engine was used to evaluate emissions characteristics. The experiments led to the following propositions:

1. Considering the composition range within which B5- and B20-based microemulsions are formed, the addition of biodiesel causes a slight decrease in the microemulsion area, indicated in a ternary phase diagram;

2. The nonionic surfactant nonylphenol ethoxylate with five oxyethylene units can be used to obtain diesel/biodiesel microemulsions, but the amount of biodiesel in the mixture must be limited;

3. The values of density and flash point for all studied systems were higher than those observed for neat diesel, but still in accordance with Brazilian legislation;

4. Viscosity values for all microemulsion systems were higher than those for neat diesel, B5 and B20 blends. This is related to the presence of surfactant and, consequently, to the formation of micellar structures;
5. The corrosiveness for B20 systems was augmented due to the presence of biodiesel, however still complying with the current legislation. For microemulsion systems, although the expected behavior was an enhancement in corrosiveness due to water presence, this was not observed;

6. Compared with neat diesel, B5 and B20 blends showed a small decrease in $\mathrm{CO}$ emissions for all engine power due to the presence of oxygen in biodiesel. B5 microemulsion systems, with only 5 vol.\% biodiesel, showed increased $\mathrm{CO}$ emissions due to the presence of water. In microemulsion systems with 20 vol.\% biodiesel, a decrease in $\mathrm{CO}$ emissions was verified, prevailing the effect of biodiesel;

7. The presence of biodiesel, an oxygenated fuel, in all studied systems increased NOx formation. Nevertheless, a decrease in NOx emissions was observed with an increase in water content due to a reduction in temperature inside the combustion chamber.

8. Microemulsion systems showed an increased total unburned hydrocarbon ( $\mathrm{HC}$ ) due to a reduction in gas temperature inside the cylinder, which caused a decrease in combustion efficiency.

9. Smoke emissions from diesel/biodiesel blends (B5 and B20) and all microemulsion systems were equal or lower than those of neat diesel.

\section{ACKNOWLEDGMENTS}

The authors would like to thank and acknowledge the Brazilian Agency of Petroleum, Natural Gas and Biofuels (Agência Nacional do Petróleo, Gás Natural e Biocombustíveis - ANP) for providing financial support for this research.

\section{REFERENCES}

Abu-Zaid, M. Performance of single cylinder, direct injection diesel engine using water fuel emulsions. Energy Conversion and Management, v.45, p.697-705, 2004. http://dx.doi.org/10.1016/S0196-8904(03)00179-1 
Ahel, M.; Giger, W. Aqueous solubility of alkylphenols and alkylphenol polyethoxylates. Chemosphere, v.26(8), p.1461-1470, 1993. http://dx.doi.org/10.1016/0045-6535(93)90213-0

Andersen, W. C.; Abdulagatov, A. I.; Bruno, T. J. The ASTM copper strip corrosion test: Application to propane with carbonyl sulfide and hydrogen sulfide. Energy Fuels, v.17(1), p.120-126, 2003. http://dx.doi.org/10.1021/ef020145m

ANP (Brazilian National Agency of Petroleum, Natural Gas, and Biofuels), Resolution Number 15/2006 - Normas para comercialização de óleo diesel e misturas de óleo diesel/biodiesel-B2 automotivo (Standards for commercialization of diesel oil and diesel/biodiesel B2 automotive blends)), July 17, 2006. Available at $<$ http://nxt.anp.gov.br/NXT/gateway.dll?f=templat es\&fn=default.htm\&vid=anp:10.1048/enu> in May 2010. (in Portuguese)

ASTM D130. Standard Test Method for Corrosiveness to Copper from Petroleum Products by Copper Strip Test. American Society for Testing and Materials (ASTM), 2004.

ASTM D2156. Standard Test Method for Smoke Density in Flue Gases from Burning Distillate Fuels. American Society for Testing and Materials (ASTM), 2009.

Atadashi, I. M.; Aroua, M. K.; Abdul Aziz, A. High quality biodiesel and its diesel engine application: $A$ review. Renewable and Sustainable Energy Reviews, v.14(7), p.1999-2008, 2010. http://dx.doi.org/10.1016/j.rser.2010.03.020

Balat, M; Balat, H. A critical review of bio-diesel as a vehicular fuel. Energy Conversion and Management, v. 49, p.2727-2741, 2008. http://dx.doi.org/10.1016/j.enconman.2008.03.016

Ban-Weiss, G. A.; Chen, J. Y.; Buchholz, B. A.; Dibble, R. W. A numerical investigation into the anomalous slight NOx increase when burning biodiesel: A new (old) theory. Fuel Processing Technology, v.88(7), p.659-667, 2007. http://dx.doi.org/10.1016/i.fuproc.2007.01.007

Benjumea, P.; Agudelo, J.; Agudelo A. Basic properties of palm oil biodiesel-diesel blends. Fuel, v. 87, p. 2069-2075, 2008.

http://dx.doi.org/10.1016/i.fuel.2007.11.004
Castro Dantas, T. N.; Dantas Neto, A. A.; Silva, A. C. New microemulsion systems using diesel and vegetable oils. Fuel, v.80, p.75-81, 2001. http://dx.doi.org/10.1016/S0016-2361(00)00068-5

Cheenkachorn, K.; Narasingha, M. H.; Pupakornnopparut, J. Biodiesel as an additive for Dieselhol. In: The Joint International Conference on "Sustainable Energy and Environment (SEE)", 2004, Hua Hin, Thailand, 1-3 December.

Dantas Neto, A. A.; Fernandes, M. R.; Barros Neto, E. L.; Castro dantas, T. N.; Moura, M. C. P. A. Alternative fuels composed by blends of nonionic surfactant with diesel and water: Engine performance and emissions. Brazilian Journal of Chemical Engineering, v.28(3), p. 521-531, 2011. http://dx.doi.org/10.1590/50104-66322011000300017

Dantas Neto, A. A.; Gomes, E. A. S.; Barros Neto, E. L.; Dantas, T. N. C.; Moura, C. P. A. M. Determination of wax appearance temperature (WAT) in paraffin/solvent systems by photoelectric signal and viscometry. Brazilian Journal of Petroleum and Gas, v.3(4), p.149-157, 2009.

Dorado, M. P.; Ballesteros, E.; Arnal, J. M.; Gomez, J.; Lopez, F. J. Exhaust emissions from a diesel engine fueled with transesterified waste olive oil. Fuel, v.82,p.1311-1315, 2003. http://dx.doi.org/10.1016/S0016-2361(03)00034-6

Eurotron. Instruction Manual MM850371. $4^{\text {th }}$ Edition. In pdf. Available at: <http://www.om.gr/MM850482-04 UniGas1000.pdf> in May 2010.

Fazal, M. A.; Haseeb, A. S. M. A.; Masjuki, H. H. Biodiesel feasibility study: An evaluation of material compatibility; performance; emission and engine durability. Renewable and Sustainable Energy Reviews, v.15(2), p.1314-1324, 2011. http://dx.doi.org/10.1016/i.rser.2010.10.004

Grabowski, M. S.; McCormick, R. L. Combustion of fat and vegetable oil derived fuels in diesel engine. Progressive Energy and Combustion Science, v.97, p.125-164, 1998. http://dx.doi.org/10.1016/S0360-1285(97)00034-8

Hess, M. A.; Haas, M. J.; Foglia, T. A.; Marmer, W. N. Effect of antioxidant addition on NOx emissions from biodiesel. Energy \& Fuels, v.19, p.1749-1754, 2005.

http://dx.doi.org/10.1021/ef049682s 
Janaun, J.; Ellis, N. Perspectives on biodiesel as a sustainable fuel. Renewable and Sustainable Energy Reviews, v.14(4), p.1312-1320, 2010. http://dx.doi.org/10.1016/i.rser.2009.12.011

Kannan, G. R.; Anand, R. Experimental investigation on diesel engine with diestrol-water micro emulsions. Energy, v.36, p.1680-1687, 2011. http://dx.doi.org/10.1016/i.energy.2010.12.062

Khan, I. M.; Wang, C. H. T.; Langridge, B. E. Effect of air swirl on smoke and gaseous emissions from direct-injection Diesel engines. SAE, Paper no. 720102, 1972.

Khan, I.M.; Greeves, G.; Probert, D. M. Prediction of soot and nitric oxide concentrations in diesel engine exhaust. In: Air pollution control in transport engines. Institution of Mechanical Engineers, Paper C142/71, 205-217, 1971.

Lif, A.; Stark, M.; Nydén, M.; Holmberg, K. Fuel emulsions and microemulsions based on FischerTropsch diesel. Colloids and Surfaces A: Physicochemical and Engineering Aspects, v.354, p.91-98, 2010.

http://dx.doi.org/10.1016/i.colsurfa.2009.08.020

Lin, C.-Y.; Lin, H. A. Diesel engine performance and emission characteristics of biodiesel produced by the peroxidation process. Fuel, v.18(3), p.298305, 2006.

http://dx.doi.org/10.1016/i.fuel.2005.05.018

Lin, C.-Y.; Lin, H.-A. Effects of NOx inhibitor agent on fuel properties of three-phase biodiesel emulsions. Fuel Processing Technology, v. 89(11), p.1237-1242, 2008.

http://dx.doi.org/10.1016/j.fuproc.2008.05.022

Lin, Y. C.; Lee, W. J.; Wu, T. S.; Wang, C. T. Comparison of $\mathrm{PAH}$ and regulated harmful matter emissions from biodiesel blends and paraffinic fuel blends on engine accumulated mileage test. Fuel, v.85, p.2516-2523, 2006.

http://dx.doi.org/10.1016/i.fuel.2006.04.023

Mueller, C. J.; Boehman, A. L.; Martin, G. C. An Experimental investigation of the origin of increased NOx emissions when fueling a heavyduty compression-ignition engine with soy biodiesel. SAE International 2009-01-1792, p. 1-28, 2009.
Ochoterena, R.; Lif, A.; Nydén, M.; Sven, A.; Denbratt, I. Optical studies of spray development and combustion of water-in-diesel emulsion and microemulsion fuels. Fuel, v.89, p.122-132, 2010. http://dx.doi.org/10.1016/j.fuel.2009.06.039

Qi, D. H.; Chen, H.; Matthews, R. D.; Bian, Y. ZH. Combustion and emission characteristics of ethanol-biodiesel-water micro-emulsions used in a direct injection compression ignition engine. Fuel, v.89, p.958-964, 2010.

http://dx.doi.org/10.1016/i.fuel.2009.06.029

Rakopoulos, C. D.; Antonopoulos, K. A.; Rakopoulos, D. C.; Hountalas, D. T.; Giakoumis, E. G. Comparative performance and emissions study of a direct injection diesel engine using blends of diesel fuel with vegetable oils or bio-diesels of various origins. Energy Conversion and Management, v.47, p.3272-3287, 2006. http://dx.doi.org/10.1016/j.enconman.2006.01.006

Shariati, F. P.; Bonakdarpour, B.; Mehrnia, M. R. Hydrodynamics and oxygen transfer behavior of water in diesel microemulsions in a draft tube airlift bioreactor. Chemical Engineering and Processing, v.46(4), p.334-342, 2007. http://dx.doi.org/10.1016/i.cep.2006.07.003

Subbaiah, G. V.; Gopal, K. R.; Hussain, S. A.; Prasad, B. D.; Reddy, K. T. Rice bran oil biodiesel as an additive in diesel-ethanol blends for diesel engines. International Journal of Research and Reviews in Applied Sciences, v.3(3), p.334-342, 2010.

Subramanian, K. A. A comparison of waterdiesel emulsion and timed injection of water into the intake manifold of a diesel engine for simultaneous control of $\mathrm{NO}$ and smoke emissions. Energy Conversion and Management, v.52, p.849857, 2011.

http://dx.doi.org/10.1016/j.enconman.2010.08.010

Szybist, J. P.; Kirby, S. R.; Boehman, A. L. NOx emissions of alternative diesel fuels: A comparative analysis of biodiesel and FT diesel. Energy Fuel, v.19, p.1484-1492, 2005.

http://dx.doi.org/10.1021/ef049702q 
Tauzia, X.; Mailboom, A.; Shah, S. R. Experimental study of inlet manifold water injection on combustion and emissions of an automotive direct injection diesel engine. Energy, v.35, p.3628-3639, 2010.

http://dx.doi.org/10.1016/i.energy.2010.05.007

Turns, S.R. Understanding NOx formation in nonpremixed flames: Experiments and Modeling. Progress in Energy and Combustion Science, v 21, p.361-385, 1995. http://dx.doi.org/10.1016/0360$\underline{1285(94) 00006-9}$
Wang, F.; Fang, B.; Zhang, Z.; Zhang, S.; Chen, Y. The effect of alkanol chain on the interfacial composition and thermodynamic properties of diesel oil microemulsion. Fuel, v.87(12), p.25172522, 2008.

http://dx.doi.org/10.1016/i.fuel.2008.01.027

Zheng, M.; Mulenga, M. C.; Reader, G. T.; Wang, M.; Ting, D. S. K.; Tjong, J. Biodiesel engine performance and emissions in low temperature combustion. Fuel, v.87, p.714-722, 2008. http://dx.doi.org/10.1016/i.fuel.2007.05.039 